\title{
Exploring the Western Racial Discrimination in Languages
}

\author{
Desheng Chen \\ School of Foreign Languages \\ Wuhan Polytechnic University \\ Wuhan, China 430023
}

\author{
Ni Chen \\ Student of School of Foreign Languages \\ Wuhan Polytechnic University \\ Wuhan, China 430023
}

\begin{abstract}
The concept of "Race" is often with quotation marks, because "race" just as sex to be a social category rather than a biological category. Racial prejudice is an expression of a nation to another nation's belief. Therefore, racial discrimination is in the culture. Racial discrimination is a result of different cultures and ethnic standards. It is a kind of behavior that hostility, persecution and treating other racial with inequality. With the growing globalization and the crosscultural communication, it is necessary for us to correctly interpret the racism revealing in language culture, and reinforce the cultural sensitivity in cross-cultural communication.
\end{abstract}

Keywords—language; culture; racial discrimination

\section{INTRODUCTION}

Racial discrimination refers to based on race to divide people into different social class and then treat them differently, that means discrimination between one nation and another. (Cihai, 1989:456) They measure other races with their own cultural or ethnic standards and practices, what's more, hostility, persecution and treat other racial injustice. So far, there are many capitalist countries generally have racial discrimination. The performance of racism has public, legal, veiled, realistic, and reflected in every field.

\section{CAUSES OF RACIAL DISCRIMINATION}

Racial discrimination has always existed across the history of mankind. To make a long story short, racial discrimination all through the world is depend on the strong national pride and superiority complex. However, the basic reason of racism is the superiority of whites. White supremacists often view that some Europeans are the master race, according to their "fair" color of skin. Colonialism the pinnacle of American racial discrimination. Before the American Civil Wars, slavery was universal, a large number of blacks and indians were used as slaves. Although the slavery was abated after the Civil Wars, the colonial culture by British and French settlers still exist in "noble" white groups, especially in the South of America. That is one kind of disgusting colonial ideology and racial arrogance. The idea of racism is inveterate, blacks situation is very difficult to be completely improved in a short time. As a result of the black low status, the low level of life and received less education, blacks are hard to stand in the society, so lead to higher crime rates, in turn, all this led to the whites much more discrimination and hatred, so to speak, this is form of a vicious circle, Black became his own mainland exile.

\section{RACIAL DISCRIMINATION IN ENGLISH LANGUAGE VOCABULARY}

Language and culture has inseparable relationship, language not only is the carrier of culture but also is a social and cultural mirror, so the racial discrimination will be reflected in the language, and impact the human social communication and thinking. Roughly, there are two cases about racial discrimination in our verbal communication. First, the word itself has no discrimination meaning, but the speaker's performance shows the discrimination thoughts. For instance, a Australian Chinese teacher has encountered the racial discrimination language violence by her student. When she was in class, her student said:"That is the Asian accent.", "Look at her, her black eyes and black hair." (Australian society, 2013) Asian accent words like this are no racial discrimination here, but the sentence was expressed students discrimination against their Chinese teacher. Second, the word itself has racist meaning. Such as "Pakis" and "diaper head", these two words are racial meaning named for Pakistani and Arabian.

Through the above examples, it is easy to find racial discrimination in the language is mainly manifested in the vocabulary. Therefore, the purpose of this paper is to explore the racial discrimination from the English vocabulary.

\section{A. The Typical National Centralism Language}

When a nation's superiority to be understood as the nation is the center of the world, the ethnic centralism came into being. Ethnocentrism is composed of two Georgios "ethnos" and "kentron", the former means"nations" and the latter means "center ". (Pu Shihong, 2014:89)It is a habit that make use of their own cultural or racial or ethnic Group's standards and practices tend to measure the foreigners or groups. Ethnocentrism can produce either positive effect or negative effect. It not only can be a powerful cohesion for a country or nations, but also can become a Chauvinism. Ethnocentrism will inevitably affect the relationship between two nations.Ethnocentrism often put their own culture and value orientation as supreme, even to inflict on others. 
Britain and the United States are showed strong ethnocentrism from its name.Americans called themselves Americans. America isn't a country name originally, but is the name of a area that the contour boundary is not clear, probably refers to the whole America area, and expand to become a name for mainland and state afterwards.(Jiao Tongmei, 2009:2) In the same way, The full name of Britain is the United Kingdom of Great Britain and Northern Ireland. However, after English achieve their goal of sea dominated and has numerous colonies all over the world, they prefer to call their country "Great Britain", and "The Empire on which the sun never sets" or "The Mistress of the Seas".(Pu Shihong, 2014:89)We can see that regardless of nationality, culture or the differences between the groups in the world, they would intentionally or unintentionally show different degrees of ethnocentrism itself.

\section{B. Racial Discrimination Language Against Black People}

Among many ethnic, the very controversial and discrimination must be blacks. In history, from the black slave dynasties to the liberated, the legacy of the deep-rooted are those racial discrimination language. After a word "Nigger" appear semantic degradation, the word is the most representative. Nigger, Niggra or Niggruh is a kind of variation of "Negro". Linguists think "Negro" usually referred to the descendants of slaves who were brought to America from Africa, so the word is recognized as the most offensive and inflammatory racial epithet, and it has been described as "the most race taboo language that offend people" in English. Therefore, the word "Nigger" has become one of the few important taboo words in English. There are similar words like Jim crow, Broad nose, Thickly etc. Generally, Black, Person of color, Coon, Darkie, Nignog and Stinker all has offensive meaning. They use Welfare refers black, and Racial tension refers black living nearby. For example, there's too much racial tensional in Cleveland so I moved to West Lake. (Sang Dongyan, 2009:113)

The words related to "Nigger" or "Black" contain derogatory meaning in different degrees no matter how the words user is consciously or unconsciously, and show the discrimination against the Blacks and make them feel unhappy. For instance, a report in the "Washington Post", the mayor of Washington, a senior assistant, David Howard, in a meeting that African American were present said the word "Niggardly" and accused him made "racial discrimination" to the African groups, he later resigned.

There is also blacks once complained, "Black" words in the semantics is both lowly and ugly. The reason is that the associative meaning of "Black" always related to "Vicious" and "Evil", "Filth" and the funeral sad meaning. So something like a blackguard, black mark, black sheep, black lie, black art, these words are related to the black is disgusting.

Trina Smith give an example from her student Bob to explain the racism exists in language and everyday interactions. In a meeting discussing Bob's internship, after a rant about how people claim their race and ethnicity, a man told Bob that he could not call himself African American, charging that Bob could not trace his ancestry back to slavery or to Africa. Bob was shocked that this man had the audacity to make such a ridiculous claim. In trying to keep his cool while also advocating for himself, Bob gave the man "a short history lesson." And another story, when Bob was talking to another person at the organization, the guy told Bob "to go pick cotton." A cotton field was, literally, behind them. A black person carries the burden of experiencing racism in everyday life.

\section{The Resistance of Black to Whites' Discrimination from Blacks Language}

On the history of the United States, blacks were sold into slavery and suffer from white ruthless exploitation and persecution. Due to the long-term adherence to the racial discrimination and segregation in the United States, the discrimination of blacks is in everywhere, is regarded as inferior person, could not receive democratic rights. Black culture is deemed as heresy and their language is denigrated into "disgusting black street slang", "incorrect and nonstandard English", "lazy English", "the language of illiteracy" and "bastardized English". (Pan Dong, 2005:12) Blacks and their culture have suffering unfair treatment, so that aroused the black's hatred and disgusted to white society. They are boycott white culture, preserve their own traditional culture and keep the strong national characteristics. On the one side, they using their own vocabulary, on the other side to borrow White's vocabulary and give it different meaning, so that the Black English has bright characteristics.

Since the 1950s, Afro-American tries to maintain their ethnic characteristics vocabulary. They keep some words come from Africa, such as voodoo, hoodoo and buckro. And some word closely linked with everyday life as well, such as pinto, goober, hammer and mains queeze etc. (Pan Dong, 2005:12) Black also use some special word to describe whites, for example, black calls white Buckra, however, poor buckra and Janky board is refers to poor white.

Some black's vocabulary has make whites into confusion, but it takes a great proportion in black English.Like "bet and word" used to emphasize what the speaker himself had said. Playas refers that a human has strong social skills. All that and then some is description about human or things, means fantastic, outstanding and great. The racial characteristics in black language have become a clear proof about the resistance of black culture to white culture. Those words are common in black society, but beyond this society, they are too strange to make white people feel baffled.

They hate the dominant white people society, refuse white's social, economic and cultural values. But, black People living in the United States for many years, after all, with the white people, fusion between the two ethnic groups is inevitable. Black English also has a lot of vocabulary borrow from the mainstream position White English. But they are not invariable to bring in, they give loanwords unlike white English, even the opposite meaning to vent their anger. There is a case in point,

- Girl, you bad! 
- Babe, shut up the interesting story.(Pan Dong, 2005:12)

In the above two sentence, bad and shut up means "bad" and "shut up" in standard English, but in Black English means "pretty" and "go on, keep on saying".

Black English influence on American society is increasing. Black occupies more and more important status in the entertainment industry. Black short drama, witty, often broadcast in the television, many words in black English also to take this opportunity into the thousands of households. Gonna and ain't, the double negation is black English grammar characteristics, the most influential is that Reagan in the 1984 presidential campaign, use only black English sentence in public,"you ain't seen nothing yet", (Sang Dongyan, 2009:114) to show his attitude to the American black and the method and purpose of uniting blacks. At the same time, it shows the status of the blacks in the United States is increasing day by day.

\section{CONCLUSION}

Nowadays, multi-cultural violently collide each other, at the same time, in order to coexist, different cultural inevitably accept to unite. As language culture scholars, we not only should thoroughly to understand and face up to the cultural background of these racial discrimination words and meanings in different contexts, but also cautious with this kind of words, and learn to use other acceptable race called to replace these negative words, use euphemism to weaken its discrimination meaning. Last but not least, as language scholars, we also should pay attention on the specific environment and object of communication, treat them depend on the clearly field, tenor and mode, reach to avoid the failure because of misunderstand in crosscultural communication.

\section{REFERENCES}

[1] Keith Allan, Kate Burridge. Forbidden Words: Taboo and the Censoring of Language. [M]. England: Cambridge Univ Pr., 2006.

[2] Douglas Robinson. Translation and Taboo. [M] Northern Illinois University Press, 1996.

[3] Hill, Jane H. The Everyday Language of White Racism. [M]. WileyBlackwell, 2008.

[4] Donald K. Gordon. Hurtful Words: Language and Racism. [M]. Black Rose Books, 2011

[5] Judith S Neaman; Carole G Silve. KINDWORDS:A Thesaurus of Euphemisms Fxpanded and Revised Edition. [M]. Avon Books ,1991. 